Article

\title{
Improved Framework for Assessing Vulnerability to Different Types of Urban Floods
}

\author{
Quntao Yang ${ }^{1,2} \mathbb{D}$, Shuliang Zhang ${ }^{1,2, *}$, Qiang Dai ${ }^{1,2}$ and Rui Yao ${ }^{1,2}$ \\ 1 Key Laboratory of VGE of Ministry of Education, Nanjing 210023, China; yang_1990@outlook.com (Q.Y.); \\ qd_gis@163.com (Q.D.); yaorui1226@163.com (R.Y.) \\ 2 School of Geography, Nanjing Normal University, Nanjing 210023, China \\ * Correspondence: zhangshuliang@njnu.edu.cn
}

Received: 18 August 2020; Accepted: 15 September 2020; Published: 17 September 2020

\begin{abstract}
Vulnerability assessment is an essential tool in mitigating the impact of urban flooding. To date, most flood vulnerability research has focused on one type of flood, such as a pluvial or fluvial flood. However, cities can suffer from urban flooding for several reasons, such as precipitation and river levee overtopping. Therefore, a vulnerability assessment considering different types of floods (pluvial floods, fluvial floods, and compound flooding induced by both rainfall and river overtopping) was conducted in this study. First, a coupled urban flood model, considering both overland and sewer network flow, was developed using the storm water management model (SWMM) and LISFLOOD-FP model to simulate the different types of flood and applied to Lishui, China. Then, the results of the flood modeling were combined with a vulnerability curve to obtain the potential impact of flooding on different land-use classes. The results indicated that different types of floods could have different influence areas and result in various degrees of flood vulnerability for different land-use classes. The results also suggest that urban flood vulnerability can be underestimated due to a lack of consideration of the full flood-induced factors.
\end{abstract}

Keywords: flood vulnerability; urban pluvial flood; fluvial flood; compound flood; flood modeling

\section{Introduction}

Floods are one of the most frequently occurring and destructive natural disasters, and often cause significant losses in cities, which are social and economic centers [1,2]. Due to global climate change, extreme hydrometeorological events result in more frequent and severe urban flooding [3-5]. Urbanization is taking place worldwide, and urban infrastructure, such as municipal drainage systems, cannot accommodate urban development and expansion. This has resulted in more frequent urban flooding and numerous social and economic problems [6-9]. Especially in developing countries such as China, which are in the process of rapid urbanization and subject to the impact of global change, urban floods have become a critical problem hindering sustainable urban development [8,10-12]. Therefore, methods of mitigating the risk of urban flooding have become a pressing topic for many cities around the world. Vulnerability assessments have great significance in revealing and reflecting the risk of urban flood disasters and have become an essential component of flood risk management in urban areas $[13,14]$.

Abundant research on flood vulnerability has contributed to improving the assessment of urban flood risks [15-17]. Most of the recent research on flood vulnerability and risk consider only one type flood or one flood inducing factor, such as pluvial floods, fluvial floods, and surge storm floods [18-24]. However, due to complicated hydrometeorological conditions and their physical environment, cities often face various flood-inducing circumstances, such as excessive precipitation, river levee overtopping, and storm surges. Therefore, a single flood type cannot reflect the real flood 
risk in an area. When multiple flood-inducing factors coincide with each other, they can result in a more severe compound flooding event $[25,26]$. The Asian region, such as China and Bangladesh, which have long suffered from various types of floods, are concerned in many compound flood studies [27-29]. Meanwhile, owing to climate change, extreme rainfall can aggravate the incapability of drainage infrastructure and increase the risk of compound flooding in Chinese cities [26,30,31]. Therefore, it is necessary for different types of floods to be considered in urban flood vulnerability assessment. However, considering different flood types makes flood modeling and vulnerability assessment in urban areas more difficult.

Flood modeling, which can be used to simulate and express detailed flood hazard information, has been widely used in research on flood risk and vulnerability $[14,19,32,33]$. Historical flood records are the data commonly used for this, but these data are not precise enough to meet the requirements for vulnerability studies for various flood scenarios, especially at the micro scale. Flood modeling should compensate for shortcomings of historical disaster data. Flood information, including inundated extent, water depth, and velocity from hydrological or hydrodynamic models can display simulations and the complete flood evolution processes of different flood scenarios. Owing to the complexity of urban terrains and municipal drainage systems, including a large number of urban drainage pipelines and artificial drainage infrastructure, flood modeling for urban areas is challenging. Presently, the 1D-2D coupled model is considered a reasonable solution, and coupled modeling software, including MIKE URBAN [34], SOBEK [35], InfoWorks ICM [36], and PCSWMM [37], has been used to model urban floods. However, most of these models are commercial software with copyrights, and their high costs limit their use for education and research. Fortunately, previously done research can provide a valuable reference and allow us to implement certain commercial software functions based on open-source models or software [38-40].

The choice of method is also important in vulnerability assessment. The indicator-based method and the vulnerability curve method are the most commonly used research methods in vulnerability assessment [13,41-43]. The vulnerability indicator method is based on the definition and determination of vulnerability. The selection of indicators and the assignment of their corresponding weights are the primary characteristics of this method, but these factors are accompanied by uncertainties. As a quantitative research method, the vulnerability curve method primarily uses the relationship between hazardous factors and damage caused by flood disasters to measure flood vulnerability. Water depth is often used as the hazardous factor in flood vulnerability assessment, and the vulnerability curve is also referred to as the depth-damage curve or depth-damage function $[44,45]$. In research on vulnerability and risk, the choice of methods is often limited by the specific aim of the research and the existing research conditions. However, regardless of the method used, data play a crucial role in the study of vulnerability. Vulnerability assessment using the indicator-based method at a micro scale is limited by the availability of data and lack of corresponding scale data [46]. In the case of developing countries, the disclosure of data, such as socioeconomic statistical data, is often restricted. Therefore, use of the indicator-based method is likely to be constrained by data unavailability. For vulnerability curve-based approaches, it is possible to overcome these limitations using remote sensing, internet data, and drawing on data from other regions [47].

These then are the motivations of this study, where an assessment framework for assessing vulnerability to different types of urban flooding was constructed. A consideration of the different types of floods in urban areas would determine the real risk of urban flooding and improve local urban flood risk management. The realization of the framework relies on the urban flood modeling and vulnerability curve method. Therefore, a coupled model based on open-source models was built and used to accommodate different causes of urban flooding, such as rainfall, river overtopping, and sewer network overflow. Then, a vulnerability curve or depth-damage function used the flood depth obtained from flood modeling to assess the potential flood impact on an area. Finally, this framework was applied to a case study area in a riverine city, Lishui in China.

The remainder of this paper is organized as follows: Section 2 describes the methodology, including flood modeling and the assessment method of flood vulnerability. The case study area and study data 
are also introduced in this section. Section 3 describes the results of flood modeling and vulnerability. Sections 4 and 5 present the discussion of the results and the conclusions of the study, respectively.

\section{Materials and Methods}

\subsection{Study Area}

A partial area of Liandu District, the primary urban area in Lishui City, China, was selected as the study area (Figure 1). Lishui City is located adjacent to the Oujiang River and covers approximately $40 \mathrm{~km}^{2}$ of low-lying urban area. Lishui is one of the most flood-prone cities in Zhejiang Province, and has a subtropical monsoon climate with an annual average rainfall of $1733 \mathrm{~mm}$. The area frequently suffers from heavy rains, especially in July and August, when plums are ripe. Therefore, this period is called the plum rain season, or East Asian rainy season, which is a common climatic phenomenon in the middle and lower reaches of the Yangtze River and Eastern China. Lishui City is vulnerable to fluvial floods due to its location in the middle and lower reaches of the Oujiang River, near the confluence of its tributary Haoxi River and the trunk stream of the Daxi River. Although Lishui is not a coastal city, it is frequently affected by typhoons due to its close proximity to the East China Sea. Therefore, pluvial floods, accompanied by typhoons and heavy rainfall, often occur in the study area. The latest severe flood event that occurred in the study area was on 20 August 2014. In that incident, the entire Oujiang basin experienced continuous heavy rainfall, which eventually led to a 50-year flood. A considerable loss of property was caused by fluvial flooding and severe urban flooding.

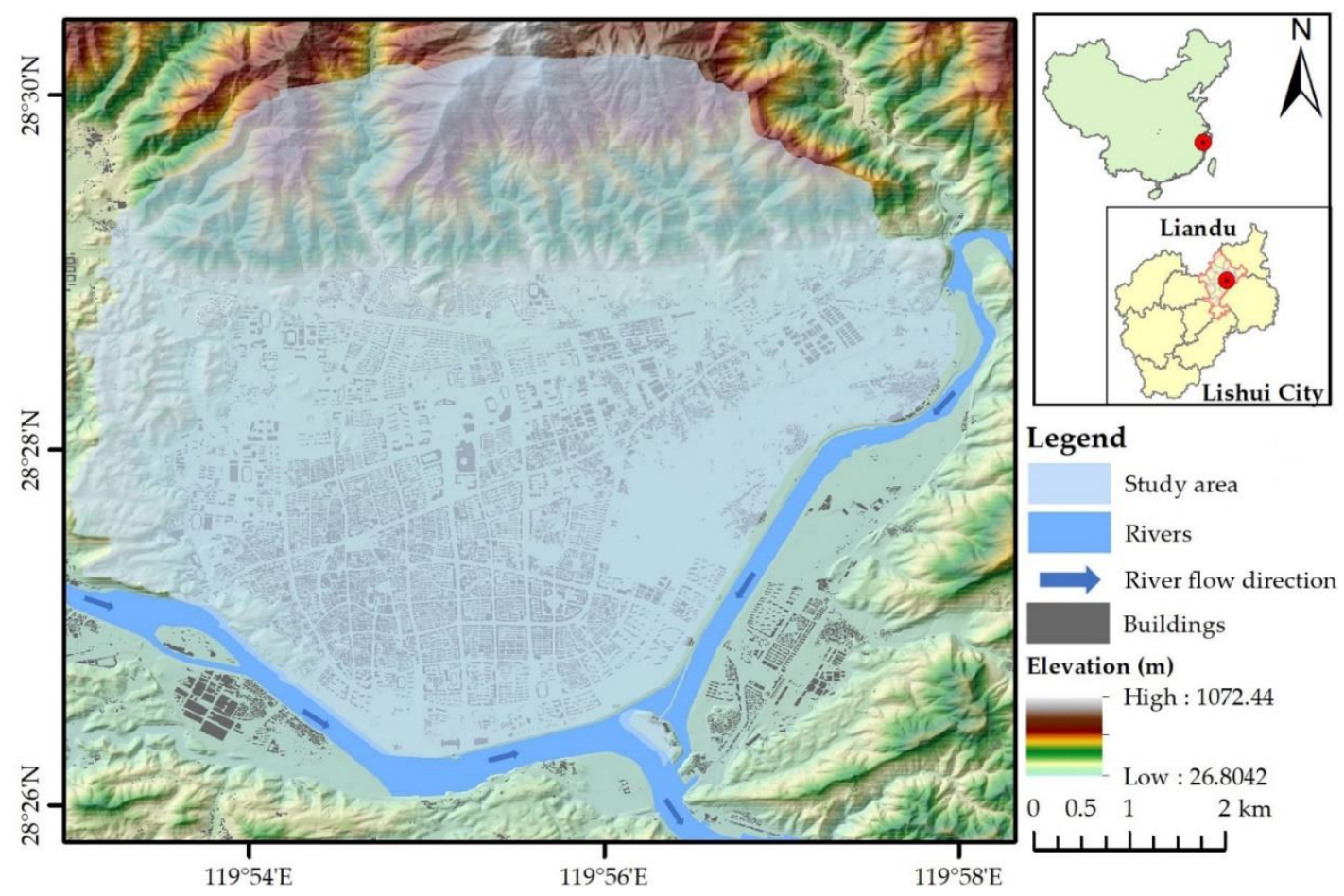

Figure 1. Location and geographical characteristics of the study area.

\subsection{Methodological Outline}

The research procedure was divided into two parts: flood modeling and vulnerability curve calculation. First, a coupled urban flood model was built using the LISFLOOD-FP model [48] and storm water management model (SWMM) [49], which were used to simulate three types of urban floods; fluvial floods, urban pluvial floods, and compound flooding induced by rainfall and river flooding. Then, the land-use classes were identified using local geographic data and high-resolution aerial images. Finally, flood vulnerability was determined by different vulnerability curves based on 
water depth from flood modeling and the corresponding land-use class. The detailed research outline is presented in Figure 2.

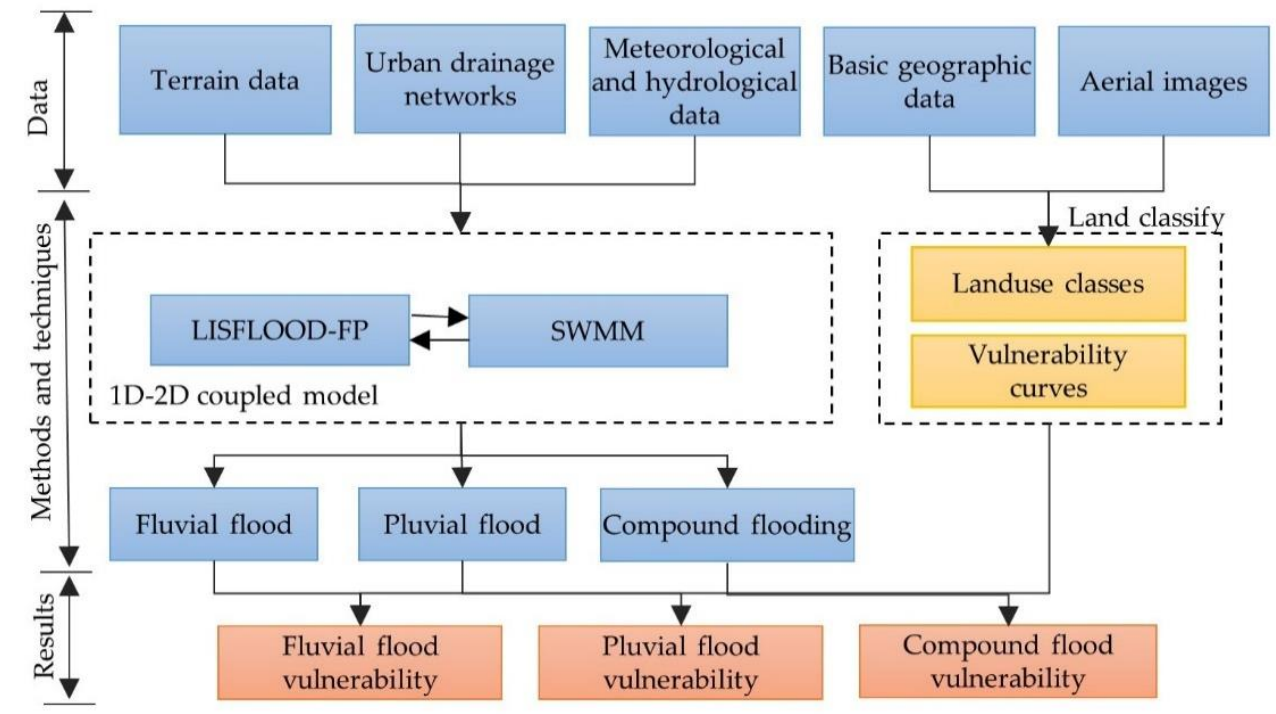

Figure 2. Outline of the flood vulnerability assessment.

\subsection{Flood Modeling}

Historical observation records, which can be used for statistical analysis of the frequency of floods and the impact extent of historical floods, are the primary source of flood information. However, these observation records cannot describe the detailed process and characteristics of a specific flood event, such as the water depth and velocity in the inundated places. For many places, historical observation data are incomplete or lacking, especially in underdeveloped or ungauged areas. Therefore, flood modeling can be used to obtain detailed flood information with the use of limited hydrometeorological observation data.

Flood modeling is also a challenge in urban areas, where drainage processes are generally more complex than in natural catchments. Therefore, urban flood models need to simulate a mass of artificial drainage infrastructure, such as pipe networks and pumps. For compatibility with urban drainage conditions, a 1D-2D coupled model that can be used to simulate complex flood inundation scenarios in urban areas was built for this study. To implement the model, the SWMM [49] and LISFLOOD-FP [50] were used. The SWMM is the most frequently used model in urban flood and low-impact development (LID) research. As a hydrologic-hydraulic model, the SWMM can simulate surface runoff using a hydrology model and contains hydraulic modeling capabilities used to route runoff and external inflows through the drainage system network of pipes, channels, storage/treatment units, diversion structures, and various hydrological processes that produce runoff from urban areas [51]. In the coupled model, LISFLOOD-FP is selected as the 2D model. LISFLOOD-FP is a hydrodynamic model based on structure raster data with the capacity to simulate 1D river flow and 2D overland flow. Therefore, the coupled model can simulate different types of urban floods.

In urban drainage processes, runoff is generated by rainfall that drains through the municipal sewer network. Flooding can occur where the runoff exceeds the capacity of the drainage network, and the above scenario can be incorporated into the SWMM. However, the SWMM cannot simulate how the excess runoff flows on the surface and the extent affected by the urban flood, and this is one of the shortcomings addressed by coupling the 2D inundated model. The excess runoff enters the 2D model as the surface flows through the link between the 1D and 2D models, and the remaining surface runoff will re-enter the 1D model until the drainage capacity is restored. This is achieved using the LISFLOOD-FP model. The exchanged discharge between the two models can be calculated by comparing the water level in the 1D and 2D models with the weir and orifice equations. In terms of 
practical implementation, the coupled model was developed using Python programming language, which lets the two models interoperate as a glue language. Similar methods in coupled flood models can be found in other research $[38,40,52]$.

For flood simulation, model calibration and validation are also necessary. The coupled model calibration and validation are limited by the lack of information from historical hydrographs and hyetographs due to the use of three types of floods in this study. In the pluvial flood scenario, the model was calibrated with rainfall events and validated with the four inundated locations in the field. For the fluvial flood, the model was calibrated with the hydrograph data of the last flood event that occurred in 2014, and the validation did not include a hydrograph of other events. The compound flood calibration and validation were not implemented, owing to a lack of historical records and corresponding hydrograph and hyetograph data.

\subsection{Measuring Flood Vulnerability}

In this study, an approach based on vulnerability curves and land use was used to assess vulnerability to urban flooding. The vulnerability curve describes the relationship between the potential loss of land-use elements and water depth in the flooding area. Different land-use classes require corresponding vulnerability curves. In the vulnerability assessment process, water depth and land-use classes are identified from the results of flood modeling and land-use data, and vulnerability results are obtained from the corresponding vulnerability curves.

The vulnerability curves for Asia were extracted from the global flood depth-damage database [53], which was established by determining maximum damage values based on construction cost surveys from dozens of countries. The vulnerability curve data are shown in Figure 3. To more accurately present the conditions in the study area, some adjustments were made, such as allowing for prescribed elevations in buildings. For example, according to the General Civil Building Design Code (JGJ 37-2007) [54], which is a construction industry standard in China, the ground elevation of the indoor level of buildings should be $0.15 \mathrm{~m}$ above the outdoor level. Therefore, urban buildings should not be affected by flood levels below $0.15 \mathrm{~m}$. In the vulnerability assessment, the vulnerability function should thus first subtract $0.15 \mathrm{~m}$ from the water depth.

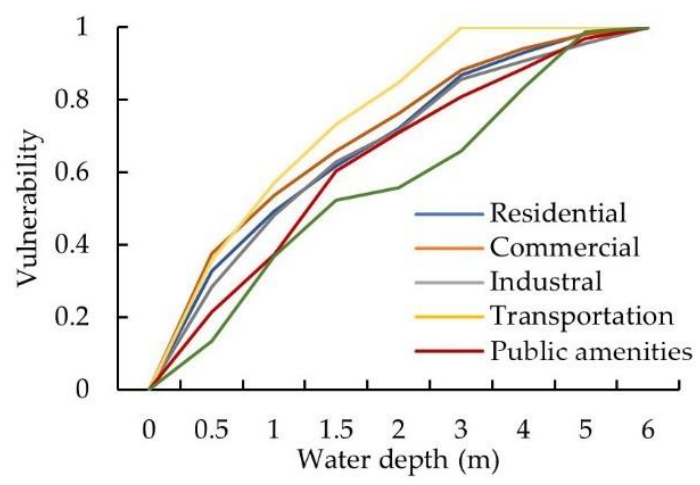

Figure 3. Vulnerability curve used in the study [53].

\subsection{Data Requirements and Availability}

For flood modeling, abundant spatial geographic data and hydrometeorological data were collected and used in the 1D-2D coupled model, including terrain data, data on urban drainage systems, and hydrological observatory data. The terrain data provided by the Lishui Geographic Information Center (LSIC), which is a local authoritative surveying and mapping department, includes digital elevation model (DEM) data with $5 \mathrm{~m}$ resolution and cross-section data of the Oujiang River. To obtain complete raster topographic data, the river area in the DEM was replaced by bathymetric data, which were obtained from the interpolation of river cross-section data. The LSIC also provided urban drainage system data, which refer to the geometry and property data of drainage infrastructure systems, 
including urban inland rivers and channels, municipal sewer networks, and related infrastructure, such as pumps and manholes. To allow the drainage networks to be absorbed by the coupled model, the sewer pipelines need to be generalized. In the generalization, the primary pipelines were retained and the intricate details were removed. After the model was built, hydrological and meteorological data (i.e., the flood-inducing factors) include rainfall and river discharge. The rainfall data were calculated using the rainstorm intensity formula, and the parameters were provided by the Lishui Meteorological Bureau. The time series of river discharge and stages upstream and downstream were obtained from the Lishui Hydrologic Station records of the 50-year flood event on 20 August 2014.

Land-use class data, which are essential data for flood vulnerability assessment using the vulnerability curve method, were extracted from urban geographic surveying and planning data. To keep the data current, the land-use data were updated using high-resolution aerial images. These geographic surveying and planning data and aerial images were provided by the LSIC. Finally, the study area was grouped into 7 land-use classes and divided into 1114 blocks following roads, rivers, or channels to facilitate vulnerability assessment and results analysis. The detailed land-use classes and divided blocks are shown in Figure 4 and the explanation and description of each land-use class are listed in Table 1.

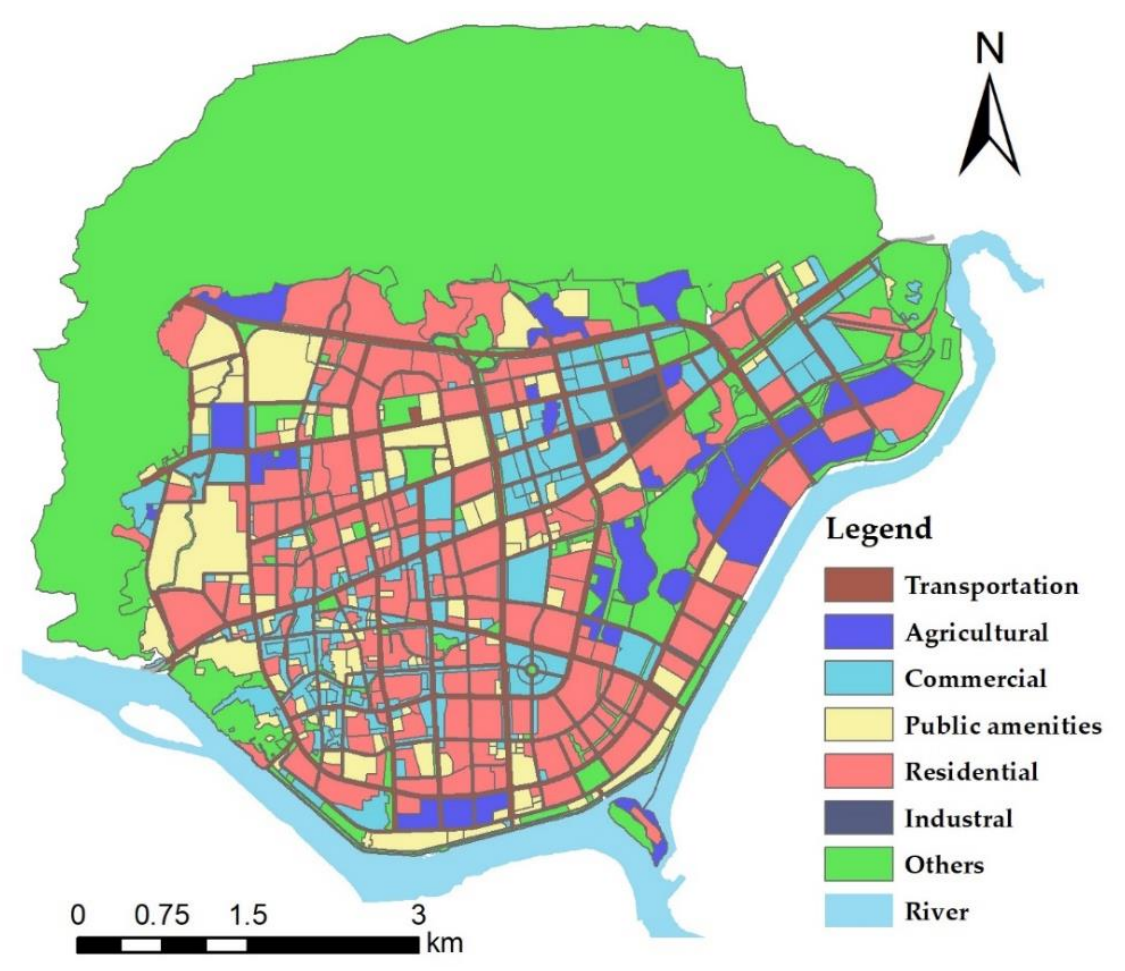

Figure 4. Land-use classes and blocks in the study area.

Table 1. Classification of land use in the study areas.

\begin{tabular}{ccr}
\hline Code & Land-Use Classes & Description \\
\hline 1 & Residential & Used for residential living, such as apartments, houses, and other residential dwellings. \\
\hline 2 & Commercial & Used for financial services, offices, restaurants, shops, hotels, and other commercial purposes. \\
\hline 3 & Industrial & Used by industries, such as manufacturing plants and warehouses. \\
\hline 4 & Transportation & Used for transport-related infrastructure, such as roads, railway lines, and highways. \\
\hline 5 & Public amenities & Includes public buildings and facilities. \\
\hline 6 & Agriculture & Used for farming activities at suburban level. \\
\hline 7 & Others & Natural areas that are not susceptible to flooding, such as forestry, lakes.
\end{tabular}




\subsection{Flood Modeling Scenarios}

Considering the physical and hydrometeorological conditions of the study area and the aim of the research, different disaster scenarios were simulated in this study. Three types of floods and corresponding scenario sets were defined, based on flood-inducing factors: pluvial flood scenarios, fluvial flood scenarios, and compound flooding scenarios. Except for the fluvial flood scenario, different flood disasters were modeled and distinguished based on various return period rainfall events in the same flood scenario sets. In pluvial floods, rainfall plays a significant role, and the urban pluvial flood scenario was designed by incorporating rainfall with different return periods. A 50-year flood event occurred in 2014 as did the fluvial flood scenario. The compound flooding resulted from various return period rainfall events and combined with the 50-year fluvial flood.

\subsubsection{Rainfall Events}

As the most common flood-inducing factor in urban areas, rainfall is a crucial input parameter for urban pluvial flood modeling, and different rainfall intensities can lead to pluvial flooding under various conditions. To determine the influence of different rainfall intensities on urban floods, a series of designated rainfall events was used in the pluvial flood modeling. In this study, a method with an intensity-duration-frequency (IDF) formula and Keifer and Chu's rainfall patterns was used to generate various rainfall events as input variables for the flood model. Rainfall events with a duration of $2 \mathrm{~h}$ and 1-, 5-, 10-, 20-, 30-, 50-, and 100-year return periods were formulated for the flood modeling. According to the IDF formula obtained from the local Meteorological Department, rainfall intensity can be determined using the following equation:

$$
q=\frac{1265.3(1+0.587 \operatorname{Lg} P)}{(t+5.919)^{0.611}}
$$

where $q(\mathrm{~mm} / \mathrm{h})$ is the rainfall intensity, $t(\mathrm{~min})$ is the duration of rainfall, and $P($ year $)$ is the return period.

Keifer and Chu's rainfall patterns, which describe the temporal variation of rainfall intensity in a rainfall event, were developed for a study on stormwater flooding in Chicago and are also called the Chicago Method. In this method, the rainfall pattern has a peak, which can be controlled by the peak coefficient. The rainfall intensity before and after the rainfall peak can be obtained from Equations (2) and (3).

$$
\begin{aligned}
& i_{1}=\frac{a\left[\frac{(1-c) t_{1}}{r}+b\right]}{\left(\frac{t_{1}}{r}+b\right)^{c+1}}, \\
& i_{2}=\frac{a\left[\frac{(1-c) t_{2}}{1-r}+b\right]}{\left(\frac{t_{2}}{1-r}+b\right)^{c+1}},
\end{aligned}
$$

where $i_{1}, i_{2}$ are the rainfall intensities before and after the rain peak $(\mathrm{mm} / \mathrm{min})$, respectively; $t_{1}, t_{2}$ are the time intervals before and after the rain peak (min); $r$ is the rain peak coefficient $(0<\mathrm{r}<1)$, and the $r$ in this study is set to 0.4 , which is in line with rainfall patterns in China; and a, b, and c are the local parameters in the IDF formula. From Equation (1), the 3 values in this study are 1, 265.3, 5.919, and 0.611 , respectively.

\subsubsection{Fluvial Flood Events}

For the fluvial flood scenario, a 50-year flood event, based on the flood that occurred on August 202014 , with a duration of $24 \mathrm{~h}$, was chosen as the fluvial flood input. The local hydrometeorological conditions and flood management facilities were also considerations. The 50-year flood is the most severe flood in local flood risk management, and also, the design standard for dams in this section of the river. Fluvial floods of less than 50 years rarely cause overtopping flooding, and multiple fluvial flood scenarios create complex 
compound flood scenarios, with too many combinations of rainfall and river flooding events. Moreover, the 50-year flood event that occurred on 20 August 2014 was the most severe flood disaster since 1985. Therefore, the flood event that occurred in 2014 was used as the fluvial flood scenario in this study.

\subsubsection{Compound Flooding Scenario}

For the compound flood scenario, two methods, the GIS method and the flood modeling method, were used to express the hazard of urban compound flooding induced by rainfall and river overtopping. In the GIS method, spatial analyst tools in ESRI ArcGIS Desktop 10.8 were used to combine the simulation results from pluvial and fluvial floods. In the merging process, the results of the fluvial flood combined with the urban pluvial flood, which was induced by different return periods of rainfall, and the maximum pixel value of the two types of floods, were conveyed to the compound flooding scenario. In the alternative method, compound flooding was simulated using a coupled model similar to a fluvial and pluvial flood, and both rainfall and river discharge were used as the input parameters. However, the simulation times of the 2 types of floods are different $-24 \mathrm{~h}$ and $2 \mathrm{~h}$, respectively. To achieve the most severe flood condition, the peaks of the time series of rainfall and river overtopping at almost the same moment were used. The model settings of the three flood types are shown in Table 2.

Table 2. Flood types and input factors in flood modeling.

\begin{tabular}{ccc}
\hline Flood Types & Induced Factors & Scenarios \\
\hline Pluvial flood & Rainfall & $1-, 5-, 10-$, 20-, 30-, 50-year rainfall return periods \\
\hline Fluvial flood & River levee overtopping & 50 -year river flood \\
\hline Compound flood & Rainfall and river levee overtopping & $\begin{array}{c}50 \text {-year river flood combined with 1-, 5-, 10-, 20-, 30-, } \\
50 \text {-year rainfall return periods, respectively }\end{array}$ \\
\hline
\end{tabular}

\section{Results}

\subsection{Flood Modeling}

To describe the distribution of flood hazards corresponding to the designated scenario, the maximum water depth of the flood in the modeling process was extracted and flood maps were obtained using GIS methods, as shown in Figures 5-7.

Flood maps represent the spatial distribution and extent of flooding. In the case of the pluvial flood (Figure 5a-g), and a rainfall return period of 1 year of almost no flooding occurred in the study area. However, 171 blocks were affected by flooding when the rainfall return period was 5 years. With the increase in precipitation, the flood water depth and inundated area also increased. Almost half the blocks were affected by pluvial flooding with 100-year rainfall. The blocks were scattered over a large area-all low-lying. For the 50-year fluvial flood (Figure 5h), the number of flood-affected blocks was 171, and all of them were mainly distributed along the Oujiang River. In the northern parts of the city, which are relatively far from the river, the fluvial flood-affected areas decrease as the terrain gradually becomes elevated.

For the compound flooding scenario, the flood hazard data were obtained following two different approaches. For the first method (Figure 6), the flood maps were obtained by directly combining the maps of fluvial floods with those of pluvial floods using GIS. The fluvial flood map was separately integrated with the urban pluvial flood induced by different rainfall events, and the maximum water depth of both floods compared with each pixel in the flood maps provided the values for the compound flooding maps. Due to the addition of the fluvial flood, the results of the flood modeling show strong hazards even under the 1-year rainfall event, and in the worst-case scenario (in Figure 6), more than half the blocks were affected by compound flooding. The extent and distribution of the flooded area further expanded, and both included the low-lying areas along the river as well as urban inner areas. For the second method (Figure 7), modeling was done using rainfall and river discharge as flood-inducing parameters in the simulation, and the spatial distribution and trend of the flooding proved similar to that of the first method. The results of the flood modeling are harder to predict, especially in areas where pluvial flooding interacts with fluvial flooding. 

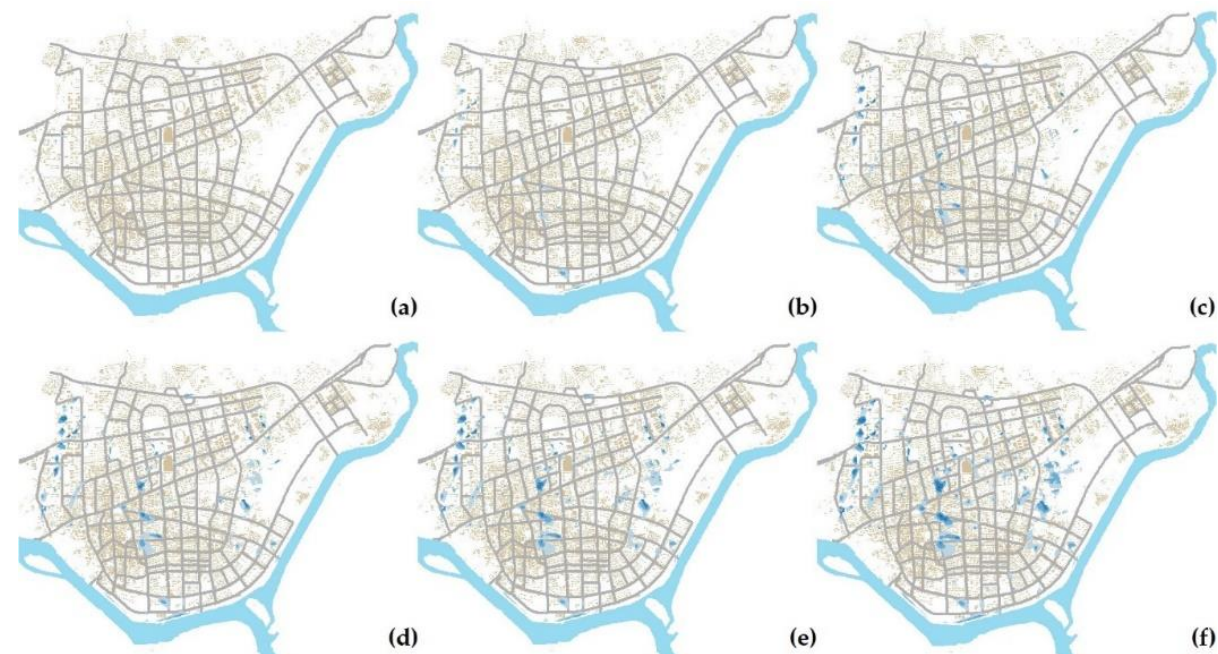

(c)

(e)
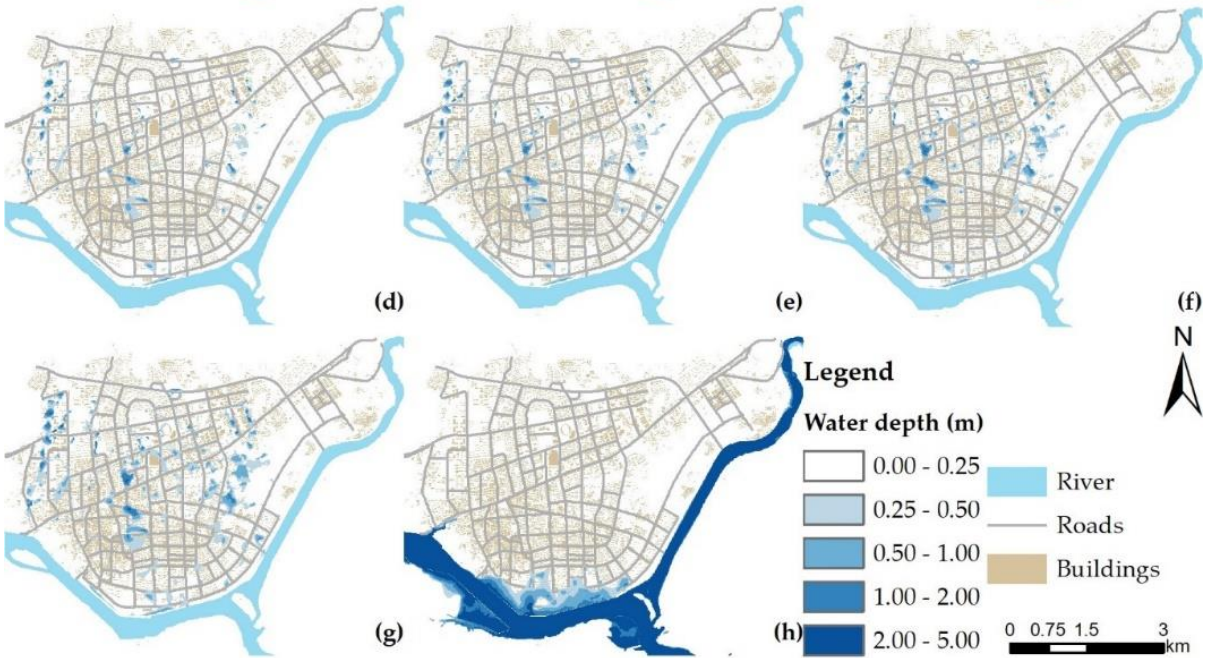

Legend

Water depth (m)

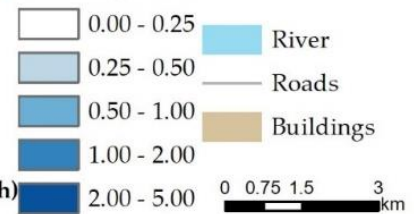

Figure 5. Flood maps from pluvial flood and fluvial flood modeling. (a-g) represent the pluvial flood with 1-, 5-, 10-, 20-, 30-, 50-, and 100-year rainfall return periods, respectively, and (h) represents the fluvial flood.
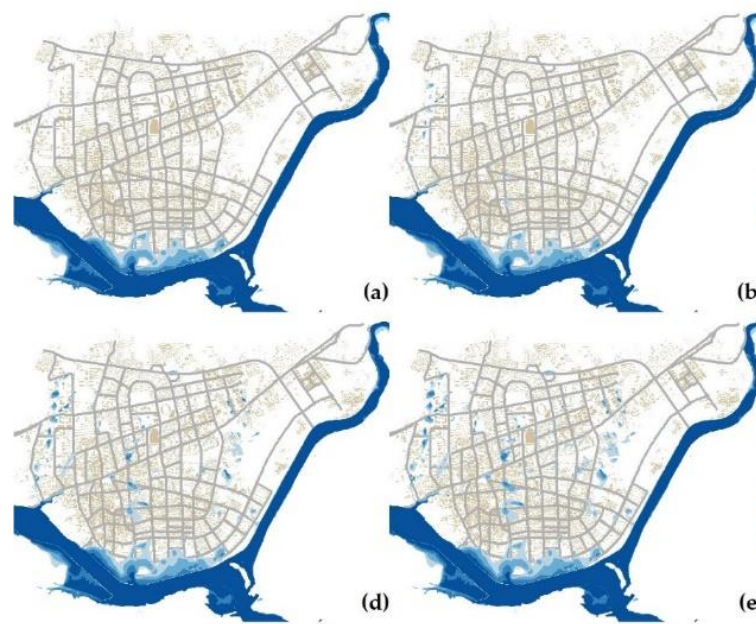

(b)
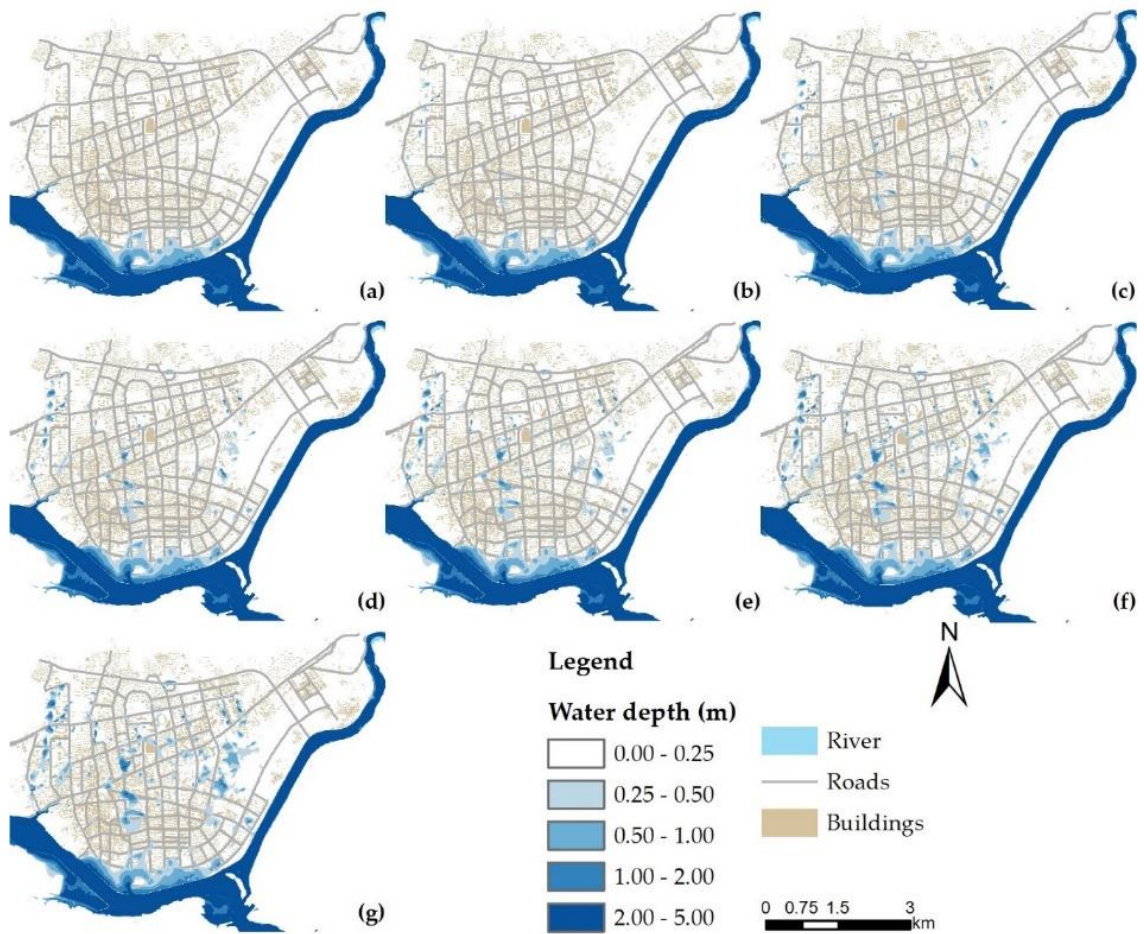

(e)

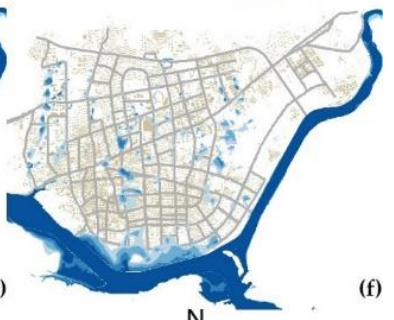

S
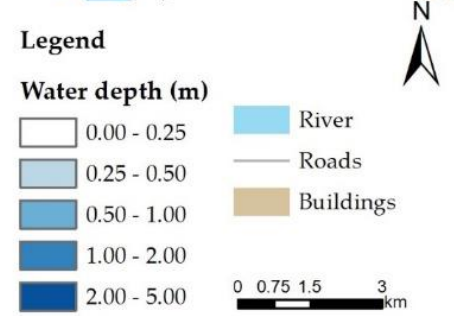

(f)

)

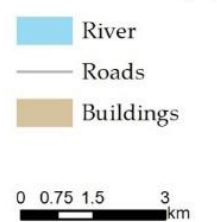

Figure 6. Flood maps of compound flood using GIS (first method). (a-g) represent the pluvial flood with 1-, 5-, 10-, 20-, 30-, 50-, and 100-year rainfall return periods, and combined with the fluvial flood, respectively. 

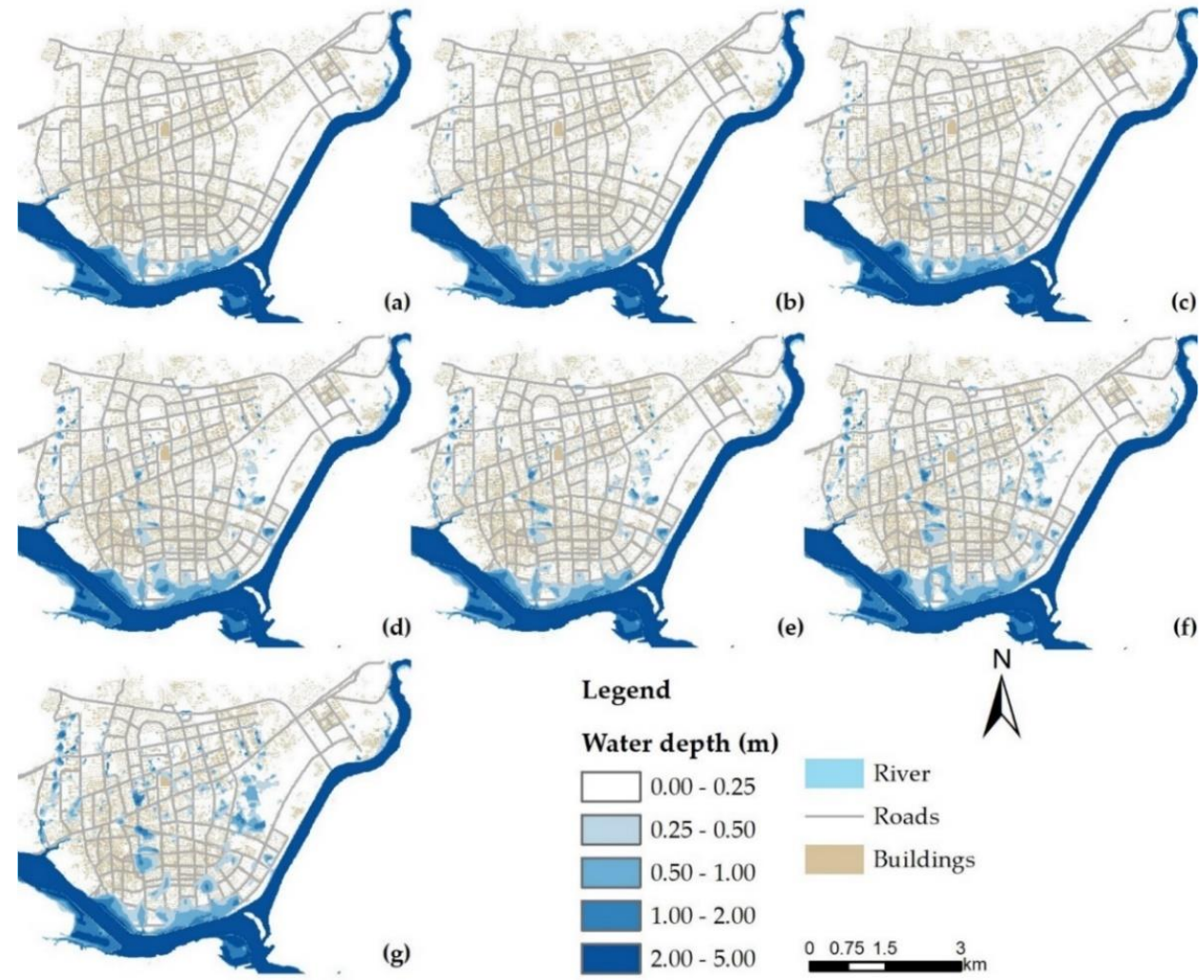

Legend

Water depth $(\mathrm{m})$
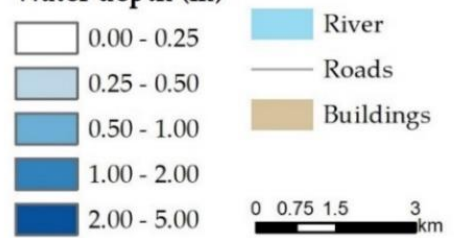

(c)

(f)

Figure 7. Flood maps from compound flood modeling done using rainfall and river overtopping as flood-inducing parameters (second method). (a-g) represent the pluvial flood with 1-, 5-, 10-, 20-, 30-, $50-$, and 100-year rainfall return periods, and combined with the fluvial flood, respectively.

\subsection{Vulnerability Assessment}

Based on the two different types of flood modeling described above, a vulnerability assessment was carried out. To clearly describe the evaluation, the assessment results are divided into four levels based on the vulnerability value range and distribution, and the classifications are shown in Table 3.

Table 3. Levels of vulnerability.

\begin{tabular}{ccc}
\hline & Vulnerability Value & Level \\
\hline 1 & $(0.0-0.1)$ & Low \\
2 & $(0.1-0.3)$ & Medium \\
3 & $(0.3-0.5)$ & High \\
4 & $(0.5-1.0)$ & Very high \\
\hline
\end{tabular}

A majority of the blocks in the pluvial and fluvial flood scenarios had a low vulnerability level (Figure 8). For pluvial flooding, almost all the blocks had low vulnerability levels under the 1- and 5-year rainfall, and as the rainfall increased, the blocks with middle and high vulnerability levels appeared and gradually increased. Under the most severe status (100-year rainfall), 116 out of 1114 blocks had a medium vulnerability level, 11 blocks had a high vulnerability level, and 2 blocks had a very high vulnerability level. For the fluvial scenario, although just 29 blocks had a medium vulnerability level, significantly more high (16) and very high (11) vulnerability blocks appeared compared to the pluvial scenario.

In the compound flood scenario (Figures 9 and 10), two similar assessment results were obtained from the two different methods, when the rainfall was 10-year or less. However, the differences in results between the two methods became clear as the rainfall intensity increased: under the 100-year 
rainfall and 50-year fluvial flood scenario, 174 blocks had a vulnerability level of medium or greater when employing GIS, and 204 blocks had a vulnerability level of medium or greater when flood modeling used rainfall and river discharge as flood-inducing parameters (second method). Thus, the vulnerability increased when doing flood modeling (second method) in the assessment, compared to when using GIS (first method).

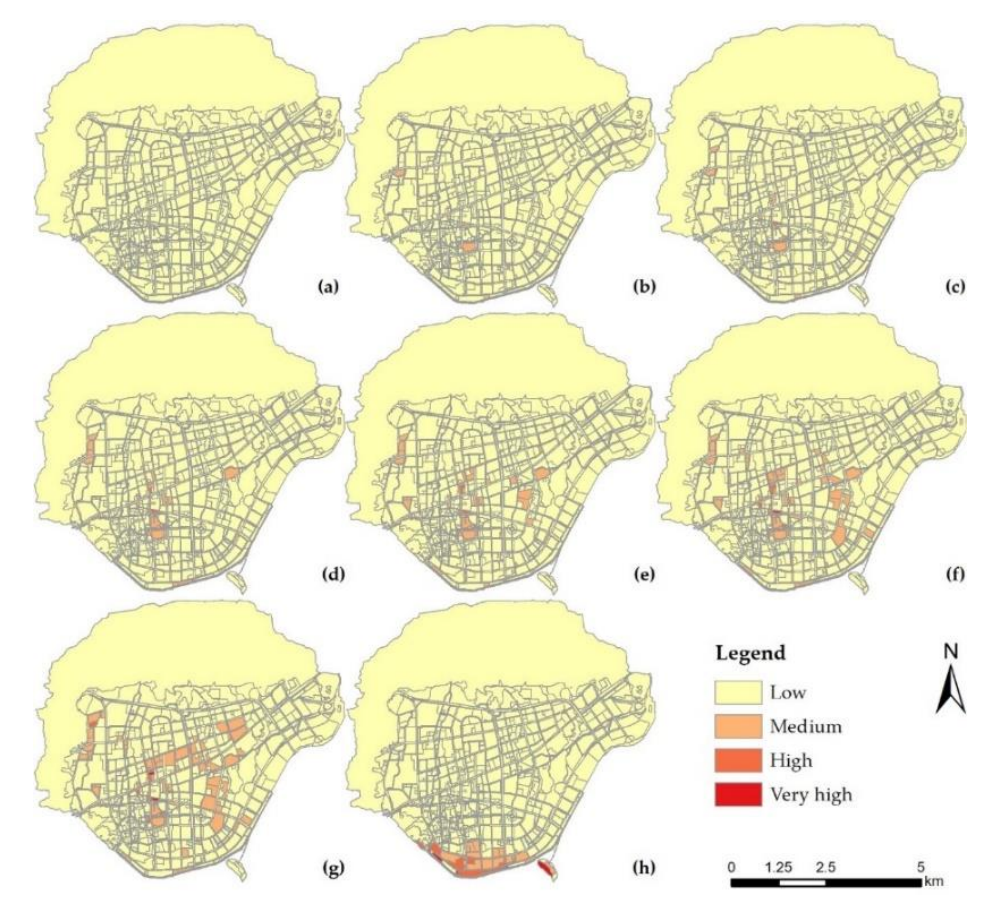

Figure 8. Vulnerability maps of the pluvial and fluvial flood. (a-g) represent the pluvial flood with 1-, 5-, 10-, 20-, 30-, 50-, and 100-year rainfall return periods, respectively, and (h) represents the fluvial flood.

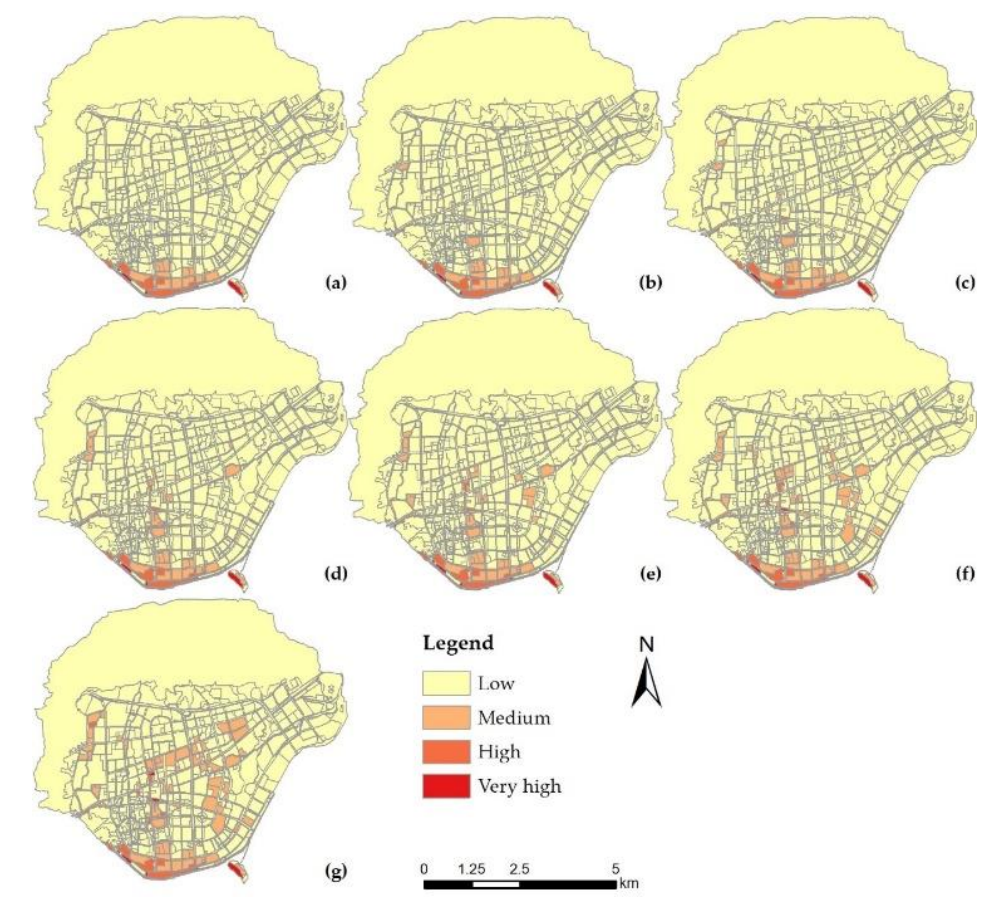

Figure 9. Vulnerability maps of the compound flood using GIS (first method). (a-g) represent the pluvial flood with 1-, 5-, 10-, 20-, 30-, 50-, and 100-year rainfall return periods, combined with the fluvial flood, respectively. 


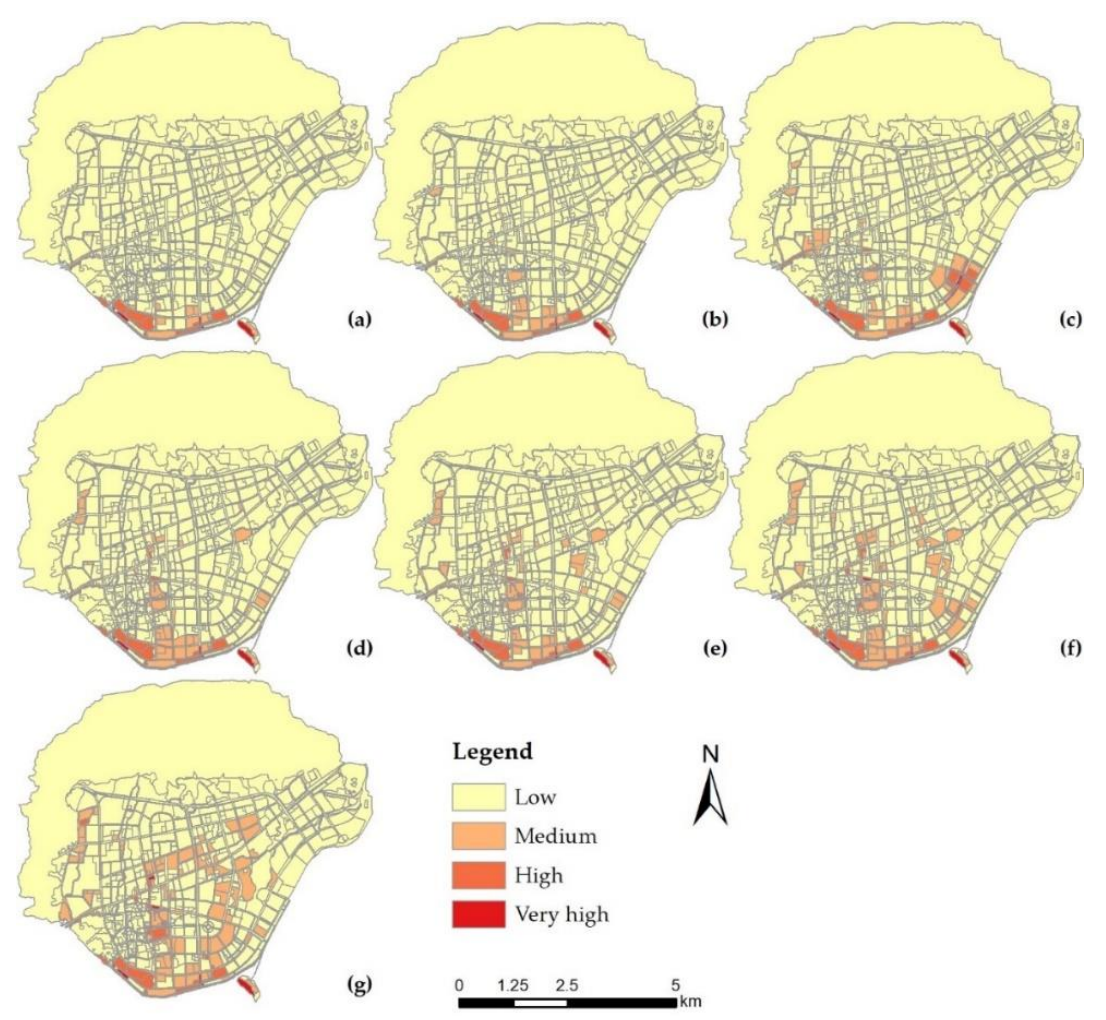

Figure 10. The vulnerability maps of the compound flood doing modeling and using rainfall and river overtopping as flood-inducing parameters (second method). (a-g) represent the pluvial flood with 1-, $5-, 10-, 20-, 30-, 50-$, and 100-year rainfall return periods, combined with the fluvial flood, respectively.

\subsection{Comparative Results}

To demonstrate the comparative results of the numbers of blocks and areas which were affected by different flood-inducing factors and methods, and to reflect the flood hazards, the number of blocks flooded and areas with water depths of more than $0.15 \mathrm{~m}$ were counted. The results are shown in Figure 11. As the fluvial flood has only one scenario, a horizontal line is displayed in the Figure 11, and the compound floods 1 and 2 represent the results obtained using the GIS method (method 1) and flood modeling (method 2), respectively.
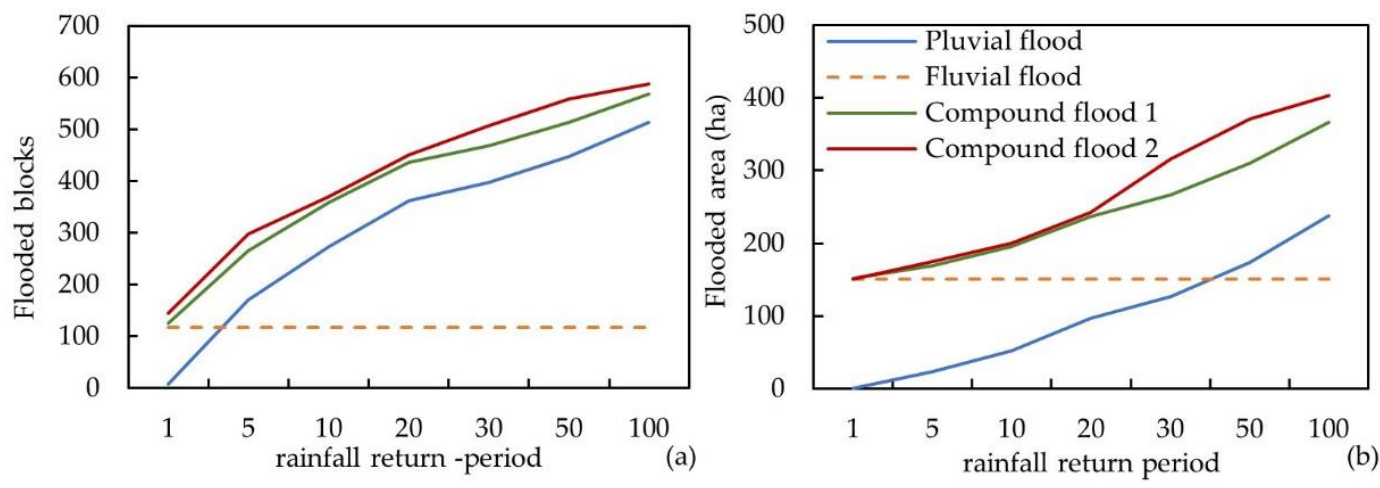

Figure 11. Representation of flooded blocks (a) and flooded areas (b) in different scenarios.

Under a series of rainfall events, urban pluvial floods and compound floods show similar trends, with the flood affected blocks and areas increasing with an increase in rainfall. Although the number of affected blocks and areas increases, the number of blocks increase faster than the flooded areas. The results of compound floods obtained by the two methods (GIS and modeling) were similar to 
each other and to that of pluvial floods when the rainfall intensity was low (10-year and lower). With an increase in rainfall, the flood modeling method showed more severe results than those of the GIS method.

A comparison of vulnerability results of different flood scenarios-in terms of affected blocks and area-are shown in Figures 12 and 13, respectively. From the comparison results of fluvial and urban pluvial floods, pluvial floods caused a significant increase in areas and blocks with medium vulnerability. Compared with extreme rainfall, although the medium and above vulnerability areas caused by fluvial flooding are not large, the area with high and very high vulnerability is evidently more than that caused by urban flooding. Compared with a flood caused by a single flood-inducing factor, a compound flood results in a greater number of medium and higher vulnerability areas. Under the two compound flood simulation methods, the results of the flood model method are more severe, resulting in more medium and high vulnerability areas, especially during extreme rainfall, such as 50-year and 100-year rainfall.
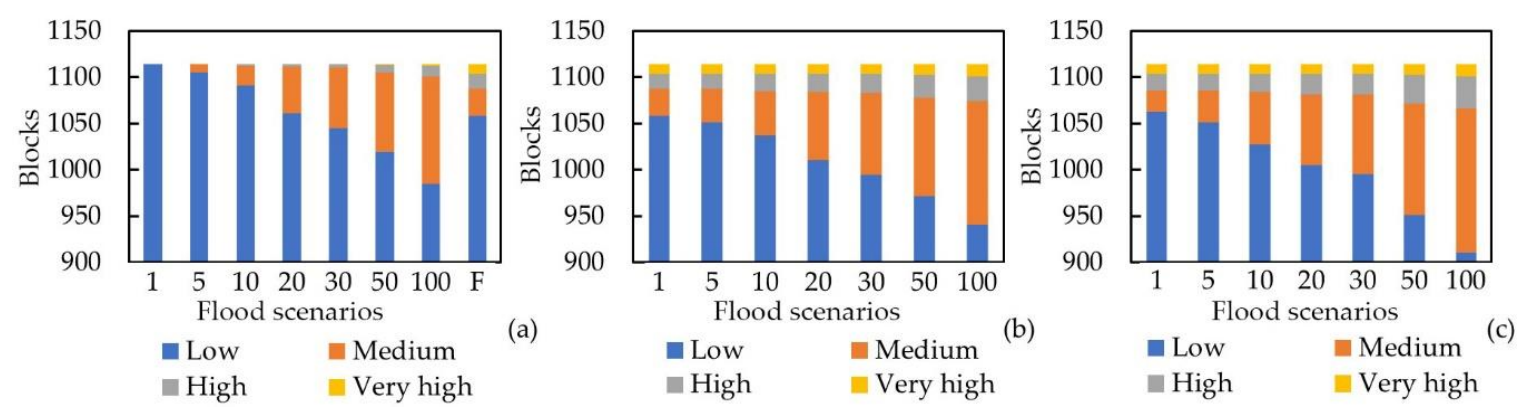

Figure 12. Number of blocks with different vulnerability levels in different flood scenarios. (a) represents blocks vulnerability in urban floods induced by 1-, 5-, 10-, 20-, 30-, 50-, and 100-year rainfall return periods and fluvial floods ( $\mathrm{F}$ in the figure); and (b) and (c) represent blocks vulnerability in compound floods from GIS and flood modeling, respectively.
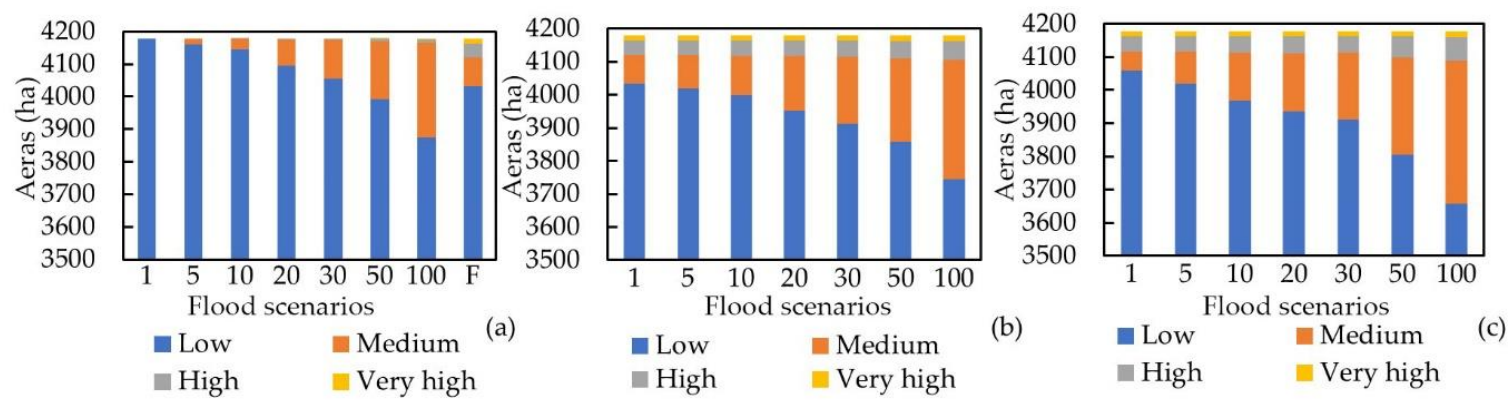

Figure 13. Areas with different vulnerability levels in different flood scenarios. (a) represents blocks vulnerability in urban floods induced by 1-, 5-, 10-, 20-, 30-, 50-, and 100-year rainfall return periods and fluvial floods ( $\mathrm{F}$ in the figure); and (b) and (c) represent blocks vulnerability in compound floods from GIS and flood modeling, respectively.

The impact of different land-use classes on the vulnerability assessment was compared (Figure 14). In the case of fluvial floods, the most affected areas were concentrated in the residential, transportation, and public amenities classes. Among the remaining flood scenarios (pluvial and compound floods), the medium and high vulnerability blocks were primarily located in the residential, transportation, public amenities, and commercial land-use classes. The industrial land is located far from the river and rarely located in the central urban area in the study case and thus, was only affected by pluvial floods. For other land-use types, although they occupied a large area of the city, vulnerability was generally low due to the limited socioeconomic impacts of floods on woodlands. 


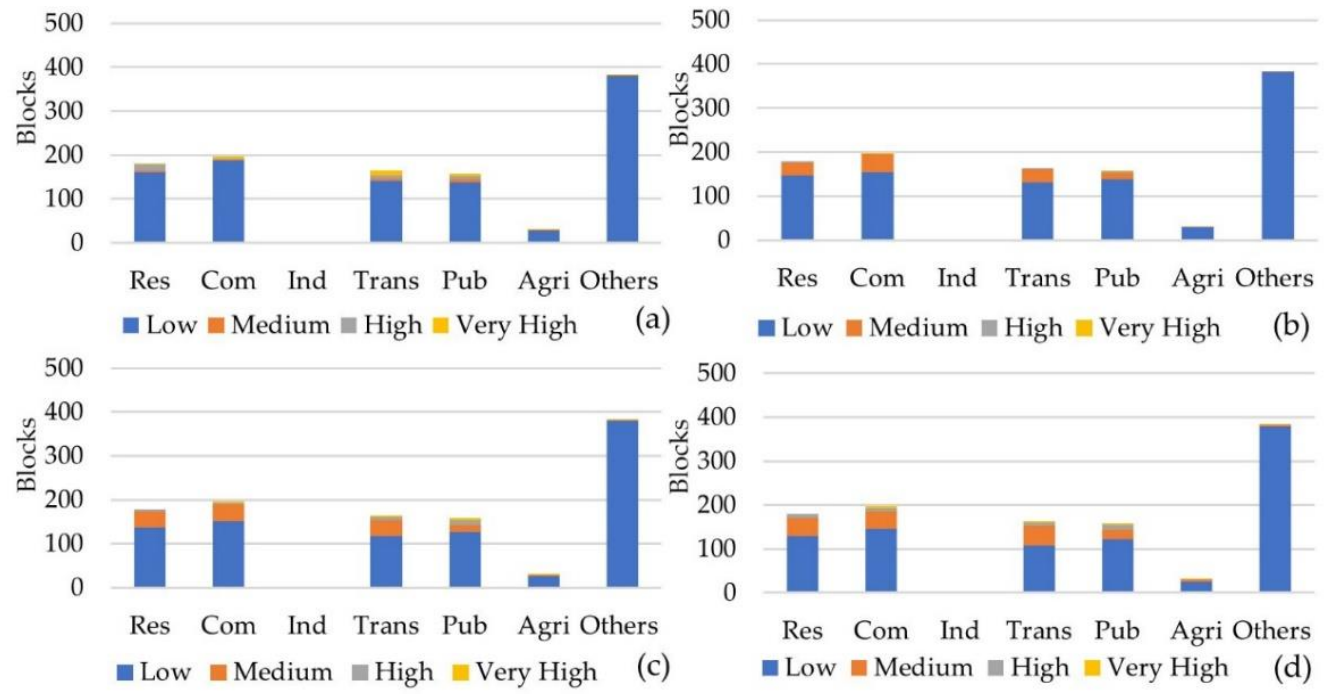

Figure 14. Blocks vulnerability levels in land-use classes under different flood scenarios. (a) represents vulnerability in pluvial floods; (b) represents vulnerability in fluvial floods; and (c) and (d) represent vulnerability in compound floods using the two methods, GIS and modeling, respectively.

\section{Discussion}

The assessment of vulnerability and risk of flood disasters requires specific targets, which can include specific objects (such as population and buildings) or composite systems (such as communities and cities). In this study, various receptors were represented by different land-use classes, which are an essential manifestation of complex social and economic systems and are frequently used in the study of disaster risk and vulnerability assessment [55-57]. The method based on land use and vulnerability curves can effectively alleviate data shortages and is frequently used in disaster risk research [56,57]. Land-use data can be obtained from remote sensing and other geographic data relatively easily, and the vulnerability curve or vulnerability function can draw on or modify data from other regions to fit the study area. Therefore, this method can use relatively few data to assess the impact of floods and is particularly suitable for urban areas $[47,56,58]$.

In many flood vulnerability studies, the flood type is set as a river flood which has the ability to cause significant damage [21,59], and river floods (fluvial floods) were, therefore, also reflected in the flood modeling of this study. The number blocks with high and very high vulnerability during a fluvial flood are significantly greater than those during an urban pluvial flood (Figure 12). However, the urban pluvial flood can cause damage comparable to river flooding when rainfall reaches a certain level, such as rainfall with a 50-year or 100-year return period, and rainfall that affected a wider area [60]. In the urban drainage process, the water levels of the rivers adjacent to the city have a significant impact on the capacity of urban drainage, and urban rainfall flows into the river, thus increasing the risk of river flooding. Meanwhile, river flooding and urban pluvial floods can interact and lead to compound flooding. Therefore, the risk and vulnerability of urban areas may be underestimated when considering a single flood-inducing factor.

Many studies propose that the impact of compound flooding is more severe than that of floods induced by a single factor [25,61,62]. This was confirmed by the results of this study (Figures 12 and 13). From the flood modeling (Figures 5-7), different flood types induced by different factors, including rainfall and river levee overtopping, can affect diverse areas. The area affected by fluvial flooding is primarily concentrated in low-lying regions distributed along the river. Due to the long distance from the river and areas with a higher elevation, the urban inner area was not affected by the river flood. For pluvial flooding, the flood-affected area is scattered in the city, including the inner and suburban areas. Compound flooding can cause greater impacts than floods induced by a single factor, and more receptors, such as population and buildings, can be affected by compound flooding in urban areas. 
The results are similar in terms of flood vulnerability, and compound flooding leads to an increase in the number of blocks with medium and high vulnerability.

Urban structure, which can influence land-use patterns [56], is an essential factor for disaster vulnerability research. From the results of vulnerability assessment and corresponding land use classes, the residential and commercial areas are the most affected in the central urban area, and public amenities and agriculture are the most affected in suburban areas. For the fluvial flood, the residential area along the river was the most affected area, and a small amount of agricultural and commercial land was also affected. The characteristics of these results are closely related to urban patterns. In the case study area, the residential and commercial land are all concentrated in the central section of the city, which is the typical structure of Chinese cities. Therefore, when flooding occurs, the central area of the city is vulnerable to severe impact.

The vulnerability assessment demonstrated that more flood adaptations are needed in the study area. The area along the river can be vulnerable to flooding, and dams should be strengthened to protect surrounding residential areas. Urban pluvial flooding also poses a significant risk because of frequent rainfall in the inner-city area. Furthermore, low impact development measures should be considered and planned in the suburban area that is undergoing rapid urbanization. Measures to accommodate different types of floods should be considered to avoid enormous damages due to flooding, especially compound flooding.

Some inevitable uncertainties exist in this study, primarily related to flood modeling and vulnerability curves data. Although the study area is ungauged, to ensure the accuracy of the flood model and its parameters, several inundation locations in the pluvial flood model were selected and validated in the field. The fluvial flood model was validated by observation records from the local hydrometric station and the authoritative flood simulation from local water resources department. However, urban flood modeling cannot be calibrated and validated quantitatively due to a lack of complete historical records of urban flood discharge. Therefore, a substantial amount of additional validation is needed to further verify the coupled model. Moreover, the vulnerability curve data used in this study were obtained from the Asian data in global flood damage research, and the functions also referenced data from Chinese cities, such as Beijing and Shanghai, in the creation process. Therefore, the use of these functions is reasonable in the case of data shortage. However, vulnerability curve data that are more appropriate for local conditions should be used in further research.

\section{Conclusions}

This study demonstrated an operable method of vulnerability assessment for different types of urban floods based on flood modeling and the vulnerability curve method. A 1D-2D coupled model combining SWMM and LISFLOOD-FP was built to simulate the different types of floods and obtain the hazard characteristics of floods including flood depth and extent of inundation. Then, simulation results combined the land-use classes and their corresponding vulnerability curves to conduct a vulnerability assessment. We described the results acquired from the application of vulnerability curves and land-use classes of different types of flood and disaster scenarios for Lishui City, China. From the results, the coupled model can accommodate multiple flood-inducing factors and reveal the hazard of urban flooding caused by heavy rainfall and river overtopping. At the same time, assessment of flood vulnerability indicated that floods induced by various factors can have different impact areas. The areas close to rivers are more vulnerable to fluvial flooding, and the areas vulnerable to pluvial flooding can be scattered over a wide range of urban areas. In addition, under the combination of various flood induced factors, compound flooding could be more harmful than floods induced by a single factor, such as pluvial or fluvial flood and lead to more vulnerable areas. In other words, urban flood vulnerability can be underestimated due to failure to consider the full flood-induced factors. Meanwhile, urban flooding primarily affects residential, commercial, transportation, and public amenities, which are the land-use classes with the highest population and socioeconomic densities and occupy most of the urban area. 
A comparative analysis of different scenarios of urban floods can provide a reference for policymakers and stakeholders for understanding the hazards of urban floods and improve urban facilities using appropriate approaches. However, the vulnerability curve method primarily expresses physical vulnerability and lacks consideration of social or economic dimensions of vulnerability. The vulnerability curves used in this study may therefore not fully reflect the vulnerability status of the study region. In future studies, the vulnerability curves need to consider additional characteristics, such as local socioeconomic conditions, and they can even be rebuilt altogether with the local data.

Author Contributions: Conceptualization, Q.Y.; Methodology and Data Analysis Q.Y.; Visualization, Q.Y.; Writing-Original Draft Preparation, Q.Y.; Writing—Review and Editing, Q.Y., Q.D. and R.Y.; Supervision, S.Z. and Q.D. All authors have read and agreed to the published version of the manuscript.

Funding: This work was supported by the National Natural Science Foundation of China (Grant Nos. 41771424, 41871299).

Acknowledgments: Special thanks are due to Lishui Geographic Information Center for providing topographic data and sewer data of the case study area.

Conflicts of Interest: The authors declare no conflict of interest.

\section{References}

1. Güneralp, B.; Güneralp, İ.; Liu, Y. Changing global patterns of urban exposure to flood and drought hazards. Glob. Environ. Chang. 2015, 31, 217-225. [CrossRef]

2. Ward, P.J.; Jongman, B.; Aerts, J.C.J.H.; Bates, P.D.; Botzen, W.J.W.; Diaz Loaiza, A.; Hallegatte, S.; Kind, J.M.; Kwadijk, J.; Scussolini, P.; et al. A global framework for future costs and benefits of river-flood protection in urban areas. Nat. Clim. Chang. 2017, 7, 642-646. [CrossRef]

3. Hallegatte, S.; Green, C.; Nicholls, R.J.; Corfee-Morlot, J. Future flood losses in major coastal cities. Nat. Clim. Chang. 2013, 3, 802-806. [CrossRef]

4. Chen, Y.; Zhou, H.; Zhang, H.; Du, G.; Zhou, J. Urban flood risk warning under rapid urbanization. Environ. Res. 2015, 139, 3-10. [CrossRef]

5. Basheer, M.; Abdul Sahib, A.; Al Madhhachi, A.S.; Al Mussawy, H. Quantifying Tigris Riverbanks Stability of Southeast Baghdad City using BSTEM. Int. J. Hydrol. Sci. Technol. 2020, 1, 230-247. [CrossRef]

6. Jiang, Y.; Zevenbergen, C.; Fu, D. Understanding the challenges for the governance of China's "sponge cities" initiative to sustainably manage urban stormwater and flooding. Nat. Hazards 2017, 89, 521-529. [CrossRef]

7. Liu, T.; Zhang, H.; Li, X.; Li, H. Effects of organization factors on flood-related Natechs in urban areas of China. Nat. Hazards 2017, 88, 355-365. [CrossRef]

8. Yin, J.; Ye, M.; Yin, Z.; Xu, S. A review of advances in urban flood risk analysis over China. Stoch. Environ. Res. Risk Assess. 2014, 29, 1063-1070. [CrossRef]

9. Rahi, K.A.; Al-Madhhachi, A.S.T.; Al-Hussaini, S.N. Assessment of Surface Water Resources of Eastern Iraq. Hydrology 2019, 6, 57. [CrossRef]

10. Zhou, Q.; Leng, G.; Huang, M. Impacts of future climate change on urban flood volumes in Hohhot in northern China: Benefits of climate change mitigation and adaptations. Hydrol. Earth Syst. Sci. 2018, 22, 305-316. [CrossRef]

11. Griffiths, J.A.; Zhu, F.; Chan, F.K.S.; Higgitt, D.L. Modelling the impact of sea-level rise on urban flood probability in SE China. Geosci. Front. 2019, 10, 363-372. [CrossRef]

12. Zhou, Q.; Leng, G.; Su, J.; Ren, Y. Comparison of urbanization and climate change impacts on urban flood volumes: Importance of urban planning and drainage adaptation. Sci. Total Environ. 2019, 658, 24-33. [CrossRef] [PubMed]

13. Nasiri, H.; Mohd Yusof, M.J.; Mohammad Ali, T.A. An overview to flood vulnerability assessment methods. Sustain. Water Resour. Manag. 2016, 2, 331-336. [CrossRef]

14. Tsakiris, G. Flood risk assessment: Concepts, modelling, applications. Nat. Hazards Earth Syst. Sci. 2014, 14, 1361-1369. [CrossRef]

15. Turner, B.L.; Kasperson, R.E.; Matson, P.A.; McCarthy, J.J.; Corell, R.W.; Christensen, L.; Eckley, N.; Kasperson, J.X.; Luers, A.; Martello, M.L.; et al. A framework for vulnerability analysis in sustainability science. Proc. Natl. Acad. Sci. USA 2003, 100, 8074-8079. [CrossRef] [PubMed] 
16. Weis, S.W.M.; Agostini, V.N.; Roth, L.M.; Gilmer, B.; Schill, S.R.; Knowles, J.E.; Blyther, R. Assessing vulnerability: An integrated approach for mapping adaptive capacity, sensitivity, and exposure. Clim. Chang. 2016, 136, 615-629. [CrossRef]

17. Fischer, A.P.; Frazier, T.G. Social Vulnerability to Climate Change in Temperate Forest Areas: New Measures of Exposure, Sensitivity, and Adaptive Capacity. Ann. Am. Assoc. Geogr. 2017, 108, 658-678. [CrossRef]

18. Aroca-Jimenez, E.; Bodoque, J.M.; Garcia, J.A.; Diez-Herrero, A. Construction of an integrated social vulnerability index in urban areas prone to flash flooding. Nat. Hazards Earth Syst. Sci. 2017, 17, 1541-1557. [CrossRef]

19. Garrote, J.; Alvarenga, F.M.; Díez-Herrero, A. Quantification of flash flood economic risk using ultra-detailed stage-damage functions and 2-D hydraulic models. J. Hydrol. 2016, 541, 611-625. [CrossRef]

20. Rahman, M.T.; Aldosary, A.S.; Nahiduzzaman, K.M.; Reza, I. Vulnerability of flash flooding in Riyadh, Saudi Arabia. Nat. Hazards 2016, 84, 1807-1830. [CrossRef]

21. Karagiorgos, K.; Thaler, T.; Heiser, M.; Hübl, J.; Fuchs, S. Integrated flash flood vulnerability assessment: Insights from East Attica, Greece. J. Hydrol. 2016, 541, 553-562. [CrossRef]

22. Huang, Q.; Wang, J.; Li, M.; Fei, M.; Dong, J. Modeling the influence of urbanization on urban pluvial flooding: A scenario-based case study in Shanghai, China. Nat. Hazards 2017, 87, 1035-1055. [CrossRef]

23. Andrade, M.M.N.; Szlafsztein, C.F. Vulnerability assessment including tangible and intangible components in the index composition: An Amazon case study of flooding and flash flooding. Sci. Total Environ. 2018, 630, 903-912. [CrossRef] [PubMed]

24. Al-Madhhachi, A.S.T.; Rahi, K.A.; Leabi, W.K. Hydrological Impact of Ilisu Dam on Mosul Dam; the River Tigris. Geosciences 2020, 10, 120. [CrossRef]

25. Paprotny, D.; Vousdoukas, M.I.; Morales-Nápoles, O.; Jonkman, S.N.; Feyen, L. Compound flood potential in Europe. Hydrol. Earth Syst. Sci. Discuss. 2018, 1-34. [CrossRef]

26. Fang, J.; Wahl, T.; Fang, J.; Sun, X.; Kong, F.; Liu, M. Compound flood potential from storm surge and heavy precipitation in coastal China. Hydrol. Earth Syst. Sci. Discuss. 2020, 1-24. [CrossRef]

27. Lian, J.J.; Xu, K.; Ma, C. Joint impact of rainfall and tidal level on flood risk in a coastal city with a complex river network: A case study of Fuzhou City, China. Hydrol. Earth Syst. Sci. 2013, 17, 679-689. [CrossRef]

28. Chen, W.-B.; Liu, W.-C. Modeling Flood Inundation Induced by River Flow and Storm Surges over a River Basin. Water 2014, 6, 3182-3199. [CrossRef]

29. Ikeuchi, H.; Hirabayashi, Y.; Yamazaki, D.; Muis, S.; Ward, P.J.; Winsemius, H.C.; Verlaan, M.; Kanae, S. Compound simulation of fluvial floods and storm surges in a global coupled river-coast flood model: Model development and its application to 2007 Cyclone Sidr in Bangladesh. J. Adv. Modeling Earth Syst. 2017, 9 , 1847-1862. [CrossRef]

30. Xiong, L.; Yan, L.; Du, T.; Yan, P.; Li, L.; Xu, W. Impacts of Climate Change on Urban Extreme Rainfall and Drainage Infrastructure Performance: A Case Study in Wuhan City, China. Irrig. Drain. 2019, 68, 152-164. [CrossRef]

31. Zhou, X.; Bai, Z.; Yang, Y. Linking trends in urban extreme rainfall to urban flooding in China. Int. J. Climatol. 2017, 37, 4586-4593. [CrossRef]

32. Bodoque, J.M.; Amérigo, M.; Díez-Herrero, A.; García, J.A.; Cortés, B.; Ballesteros-Cánovas, J.A.; Olcina, J. Improvement of resilience of urban areas by integrating social perception in flash-flood risk management. J. Hydrol. 2016, 541, 665-676. [CrossRef]

33. Yin, J.; Lin, N.; Yu, D. Coupled modeling of storm surge and coastal inundation: A case study in New York City during Hurricane Sandy. Water Resour. Res. 2016, 52, 8685-8699. [CrossRef]

34. Bisht, D.S.; Chatterjee, C.; Kalakoti, S.; Upadhyay, P.; Sahoo, M.; Panda, A. Modeling urban floods and drainage using SWMM and MIKE URBAN: A case study. Nat. Hazards 2016, 84, 749-776. [CrossRef]

35. Bruni, G.; Reinoso, R.; Van De Giesen, N.; Clemens, F.; Ten Veldhuis, J. On the sensitivity of urban hydrodynamic modelling to rainfall spatial and temporal resolution. Hydrol. Earth Syst. Sci. 2015, 19, 691-709. [CrossRef]

36. Chen, W.; Huang, G.; Zhang, H. Urban stormwater inundation simulation based on SWMM and diffusive overland-flow model. Water Sci. Technol. 2017, 76, 3392-3403. [CrossRef]

37. Abdelrahman, Y.T.; Moustafa, A.M.E.; Elfawy, M. Simulating Flood Urban Drainage Networks through 1D/2D Model Analysis. J. Water Manag. Modeling 2018. [CrossRef]

38. Wu, X.; Wang, Z.; Guo, S.; Liao, W.; Zeng, Z.; Chen, X. Scenario-based projections of future urban inundation within a coupled hydrodynamic model framework: A case study in Dongguan City, China. J. Hydrol. 2017, 547, 428-442. [CrossRef] 
39. Chen, A.S.; Leandro, J.; Djordjević, S. Modelling sewer discharge via displacement of manhole covers during flood events using 1D/2D SIPSON/P-DWave dual drainage simulations. Urban Water J. 2015, 13, 830-840. [CrossRef]

40. Leandro, J.; Martins, R. A methodology for linking 2D overland flow models with the sewer network model SWMM 5.1 based on dynamic link libraries. Water Sci. Technol. 2016, 73, 3017-3026. [CrossRef]

41. Papathoma-Koehle, M.; Gems, B.; Sturm, M.; Fuchs, S. Matrices, curves and indicators: A review of approaches to assess physical vulnerability to debris flows. Earth Sci. Rev. 2017, 171, 272-288. [CrossRef]

42. Fatemi, F.; Ardalan, A.; Aguirre, B.; Mansouri, N.; Mohammadfam, I. Social vulnerability indicators in disasters: Findings from a systematic review. Int. J. Disaster Risk Reduct. 2017, 22, 219-227. [CrossRef]

43. Papathoma-Köhle, M. Vulnerability curves vs. vulnerability indicators: Application of an indicator-based methodology for debris-flow hazards. Nat. Hazards Earth Syst. Sci. 2016, 16, 1771-1790. [CrossRef]

44. Pistrika, A.; Tsakiris, G.; Nalbantis, I. Flood Depth-Damage Functions for Built Environment. Environ. Process. 2014, 1, 553-572. [CrossRef]

45. Martínez-Gomariz, E.; Forero-Ortiz, E.; Guerrero-Hidalga, M.; Castán, S.; Gómez, M. Flood Depth-Damage Curves for Spanish Urban Areas. Sustainability 2020, 12, 2666. [CrossRef]

46. Fekete, A.; Damm, M.; Birkmann, J. Scales as a challenge for vulnerability assessment. Nat. Hazards 2009, 55, 729-747. [CrossRef]

47. Liu, J.; Shi, Z.; Wang, D. Measuring and mapping the flood vulnerability based on land-use patterns: A case study of Beijing, China. Nat. Hazards 2016. [CrossRef]

48. Bates, P.; Trigg, M.; Neal, J.; Dabrowa, A. LISFLOOD-FP User Manual; School of Geographical Sciences, University of Bristol: Bristol, UK, 2013; Available online: http://www.bristol.ac.uk/media-library/sites/ geography/migrated/documents/lisflood-manual-v5.9.6.pdf (accessed on 15 September 2020).

49. Gironás, J.; Roesner, L.A.; Rossman, L.A.; Davis, J. A new applications manual for the Storm Water Management Model (SWMM). Environ. Model. Softw. 2010, 25, 813-814. [CrossRef]

50. Bates, P.D.; Horritt, M.S.; Fewtrell, T.J. A simple inertial formulation of the shallow water equations for efficient two-dimensional flood inundation modelling. J. Hydrol. 2010, 387, 33-45. [CrossRef]

51. Rossman, L.A. Storm Water Management Model User's Manual, Version 5.1; US Environmental Protection Agency: Cincinnati, OH, USA, 2015.

52. Martins, R.; Leandro, J.; Djordjević, S. Influence of sewer network models on urban flood damage assessment based on coupled 1D/2D models. J. Flood Risk Manag. 2018, 11, S717-S728. [CrossRef]

53. Huizinga, J.; Moel, H.D.; Szewczyk, W. Global Flood Depth-Damage Functions; Publications Office of the European Union: Luxembourg, 2017.

54. Su, B.; Huang, H.; Zhang, N. Dynamic urban waterlogging risk assessment method based on scenario simulations. Qinghua Daxue Xuebao/J. Tsinghua Univ. 2015, 55, 684-690.

55. Chang, Y.-T.; Lee, Y.-C.; Huang, S.-L. Integrated spatial ecosystem model for simulating land use change and assessing vulnerability to flooding. Ecol. Model. 2017, 362, 87-100. [CrossRef]

56. Boudou, M.; Danière, B.; Lang, M. Assessing changes in urban flood vulnerability through mapping land use from historical information. Hydrol. Earth Syst. Sci. 2016, 20, 161-173. [CrossRef]

57. de Moel, H.; Aerts, J.C.J.H. Effect of uncertainty in land use, damage models and inundation depth on flood damage estimates. Nat. Hazards 2010, 58, 407-425. [CrossRef]

58. Liu, J.; Shi, Z.-W. Quantifying land-use change impacts on the dynamic evolution of flood vulnerability. Land Use Policy 2017, 65, 198-210. [CrossRef]

59. Mahmood, M.I.; Elagib, N.A.; Horn, F.; Saad, S.A.G. Lessons learned from Khartoum flash flood impacts: An integrated assessment. Sci. Total Environ. 2017, 601-602, 1031-1045. [CrossRef]

60. Tanaka, T.; Kiyohara, K.; Tachikawa, Y. Comparison of fluvial and pluvial flood risk curves in urban cities derived from a large ensemble climate simulation dataset: A case study in Nagoya, Japan. J. Hydrol. 2020, 584. [CrossRef]

61. Hao, Z.; Singh, V.; Hao, F. Compound Extremes in Hydroclimatology: A Review. Water 2018, 10, 718. [CrossRef]

62. Bevacqua, E.; Maraun, D.; Vousdoukas, M.I.; Voukouvalas, E.; Vrac, M.; Mentaschi, L.; Widmann, M. Higher probability of compound flooding from precipitation and storm surge in Europe under anthropogenic climate change. Sci. Adv. 2019, 5, eaaw5531. [CrossRef]

(C) 2020 by the authors. Licensee MDPI, Basel, Switzerland. This article is an open access article distributed under the terms and conditions of the Creative Commons Attribution (CC BY) license (http://creativecommons.org/licenses/by/4.0/). 